\title{
Incommensurability and corporate social technologies: a critique of corporate compensations in Colombia's coal mining region of La Guajira
}

\author{
Jacqueline Elyse Gilbert ${ }^{1}$ \\ Tamra Gilbertson \\ Line Jakobsen \\ University of New Hampshire, USA \\ University of Tennessee, USA \\ Roskilde University, Denmark
}

\begin{abstract}
Extractive industries increasingly use compensation measures to silence opposition, divide communities and stop resistance. Cerrejón, Colombia's largest transnational coal mining corporation, has a long history of damaging Indigenous Wayúu, Afro-Colombian and local communities' health and livelihoods. In the northeastern Colombian region of La Guajira, local communities struggle against the social and environmental impacts of coal mining. This article, based on field research conducted between 2018-2019, concludes that corporate and state-backed consultation and compensation projects are incommensurable with the damage caused by the coal mining operations and are implemented as a corporate social technology that undermines community cohesion and reinforces a power imbalance, perpetuating and enabling the expansion of damaging coal mining practices in Colombia.
\end{abstract}

Key Words: compensation, prior consultation, transnational coal mining, incommensurability, corporate social technologies, Colombia, Indigenous Wayúu

\section{Résumé}

Les industries extractives utilisent de plus en plus des mesures de compensation pour faire taire l'opposition, diviser les communautés et arrêter la résistance. Cerrejón, la plus grande société transnationale d'extraction de charbon de Colombie, a une longue histoire de dommages à la santé et aux moyens de subsistance des peuples autochtones Wayúu, des Afro-Colombiens et des communautés locales. Dans la région de La Guajira, au nordest de la Colombie, les communautés locales luttent contre les impacts sociaux et environnementaux de l'extraction du charbon. Cet article, basé sur des recherches sur le terrain menées entre 2018-2019, conclut que les projets de consultation et d'indemnisation soutenus par les entreprises et l'État sont incommensurables avec les dommages causés par les opérations d'extraction du charbon. Ils sont mis en œuvre comme une « technologie sociale d'entreprise » qui sape la cohésion communautaire et renforce un déséquilibre de pouvoir. Ils permettent et prolongent l'expansion des pratiques préjudiciables d'extraction du charbon en Colombie.

\footnotetext{
1 Jacqueline Elyse Gilbert, Alumna, Department of Anthropology, University of New Hampshire, USA; Email: jacqueline.elyse.gilbert "at" gmail.com. Dr. Tamra Gilbertson, Lecturer, Department of Sociology, University of Tennessee, USA; Email: tamragilbertson "at" gmail.com. Dr. Line J. Jakobsen, Department of Social Sciences and Business, Roskilde University, Denmark; Email: line_j_jakobsen "at" hotmail.com. The authors are equal contributors to this article. We would like to thank the Wayúu and Afro-Colombian communities who received us throughout our fieldwork. This research would not have been possible without financial sponsorship from: Fulbright US Student program, Danish Independent Research fund, WK McClure Study for World Affairs, a Swann-Shipley Fellowship; and institutional support from the Universidad de Magdalena, the University of Tennessee Sociology Department, the Universidad de La Guajira, the University of Roskilde and the Danish Institute for International Studies. Gratitude to Dr. Paul K. Gellert, Dr. Robin Sheriff, and Jessie Nord for comments on an early draft of this article. The authors also thank the two anonymous reviewers for constructive comments. Versión en español http://doi.org/10.2458/jpe.2952.16
} 
Mots clés: Compensation, consultation préalable, charbonnage transnational, incommensurabilité, technologies sociales d'entreprise, Colombie, indigène Wayúu

\section{Resumen}

Las medidas de compensación para silenciar la oposición, dividir comunidades y detener la resistencia, son cada vez más utilizadas por las industrias extractivas. En Colombia, Cerrejón, la corporación trasnacional minera de carbón más grande del país, tiene una larga historia causando daños a la salud y modos de subsistencia de comunidades locales, Afro-colombianas y particularmente, a los indígenas Wayúu. En la región colombiana de La Guajira, al noreste del país, las comunidades locales luchan contra los impactos sociales y ambientales a causa de la extracción de carbón. Este artículo, basado en trabajo de campo realizado entre 2018 y 2019, concluye que las consultas y proyectos de compensación corporativas y respaldados por el Estado, son inconmensurables con el daño causado por las operaciones de extracción de carbón. Además, estas son implementadas como una tecnología social corporativa que debilita la cohesión comunitaria y refuerza el desequilibrio de poder, perpetuando y habilitando así, la expansión de las dañinas prácticas de extracción de carbón en Colombia.

Palabras clave: compensación, consulta previa, minería de carbón trasnacional, inconmensurabilidad, tecnología social corporativa, Colombia, indígenas Wayúu

\section{Introduction}

The northeastern coastline of Colombia's Guajira Peninsula sustained numerous Indigenous Wayúu fishing villages for centuries. In 1983, a mining consortium constructed an immense port, Puerto Bolivar, on the peninsula to export coal. Today, the multinational corporation Cerrejón ${ }^{2}$ exports around 30 million tons of coal annually, leaving behind fine coal dust impacting the surrounding communities. ${ }^{3}$ In 2016, plans to expand the port were temporarily halted when a Wayúu leader from a seaside community won a protection order (tutela) to safeguard the fundamental rights of the Wayúu living near the port, including their right to a prior consultation. The foremost concern among many locals was that the coal dust was making their children sick. To the surprise of both the petitioners and the corporation, the Constitutional Court of Colombia ruled in favor of the community and ordered Cerrejón to carry out prior consultation with all "ethnic" communities within the zone of influence. ${ }^{4}$ For the village that brought this litigation against Cerrejón, the process resulted in a compensatory pittance of a mere fifteen fishing boats.

Based on long-term fieldwork with Wayúu and Afro-Colombian communities impacted by Cerrejón, this article demonstrates not only how grossly inadequate compensation agreements like this are compared to the impacts of coal mining, but also how the process is inherently divisive, stratifying, and disempowering. Drawing on our collective research we offer insight into the multiple functions of compensations through three case studies. We argue that compensation programs act as silencing mechanisms masking the wider, more structural socioenvironmental impacts shouldered by communities near Cerrejón's operations. We further maintain that compensation cannot possibly result in true reparations for communities, because the costs of the damage inflicted on natural ecosystems and local villages cannot be measured within the capitalist economic framework of money and materials. Contrary to promises of corporate social responsibility (CSR) programs, we show how compensations act as a "counter-insurrectionary device to pacify opposition and legitimize harm" (Dunlap 2018: 90). Ultimately, the strategy aims to acquiesce communities to global economic forces and make extractive economies more viable in the long term (Gilbertson 2020).

\footnotetext{
${ }^{2}$ While the authors were in the field, Cerrejón was jointly owned in equal shares of 33.33\% by BHP Billiton (UK), Anglo American (Australia) and Glencore (Switzerland), operating seven open pit coal mines that are often written about as one mine in the department of La Guajira, located in the northeastern Caribbean region of Colombia bordering Venezuela. In June 2021, Glencore began the process of taking over full ownership of Cerrejón, buying the remaining shares from BHP Billiton and Anglo American.

${ }^{3}$ In 2018, Cerrejón exported 30.5 million tons of coal, down from the 31.7 million tons exported in 2017 (Cerrejón 2019 ).

${ }^{4}$ According to corporate managers, the "zone of influence" includes around 30,000 people, divided into more than 400 communities, as well as several towns and smaller villages (personal communication April 2019).
} 
This article is based on research conducted by the authors between January 2018 and June 2019, including observations at meetings between the company, local communities, and government officials as well as semi-structured interviews with community members, NGO representatives, former Cerrejón employees, state officials and corporate representatives. The article begins with a literature review examining consultation and compensation processes. We present literature from political ecology to illustrate how social responsibility programs, community consultations and resulting compensations often work to legitimize damage, thereby safeguarding extractive projects, not people and the environment. We combine these arguments with literature exploring the incommensurability of monetary value and survivability, to make visible the ontological clash of values between mining companies and local communities. Building on the concept of corporate social technologies, we offer insight into the multiple functions of compensations through three case studies.

After a brief contextual presentation of La Guajira and the mining corporation, we outline the legal consultation and compensation parameters in Colombia. The penultimate Section of the article details the three related case studies, providing concrete examples of how the compensation processes have played out in local communities. We conclude by arguing that corporate and state-backed consultations and compensations are designed to undermine local autonomy and community cohesion, reinforcing a power imbalance that perpetuates damaging coal mining practices and destroys ecologies and communities. Compensations provide a false appearance that nature-processes can be paid for and that damages can be erased with money, while silencing opposition and building international support for corporate-led development.

\section{Corporate social technologies and incommensurable compensation}

This article seeks to critique compensation by combining two types of literature that build from political ecology and a Foucauldian lens. One branch of political ecology and environmental justice provides valuable insights into incommensurability and valuation language, while another, more emerging body of literature addresses corporate social technologies used to engineer consent among local communities affected by mining. This article combines these literatures in its exploration of compensatory devices.

The principles of compensation, as part of the broader CSR agenda, were originally elaborated through the idea of benefit-sharing as outlined by the World Bank (Wall and Pelon 2011). While there is no clear definition of CSR, it generally refers to a "range of voluntary initiatives that aim to minimize corporate bad practice" (Utting 2008: 959). ${ }^{5}$ Today, CSR is used to establish the necessary on-going social acceptance, often termed the social license to operate, which encapsulates the ability of corporations to ensure local acceptance to the extractive projects. Proponents argue that gaining and maintaining a social license to operate helps to mitigate project costs and risks while ensuring project completion, security, and a steady revenue stream (Prno and Slocombe 2012; Owen and Kemp 2017). Research shows how CSR programs have contributed to conflicts and polarization on the ground by disarticulating community criticism of corporate practices and diffusing local opposition through the creation of internal divisions within communities (Warnaars 2012; Fontana and Grugel 2016).

A growing body of literature addresses how CSR assists in advancing extraction through various means (Bebbington 2010; Franco 2014; Costanza 2016; Coleman 2018; Dunlap 2018). Rooted in Foucauldian thought, the term corporate social technologies is used in this article to portray corporations' efforts to shape social and cultural life (Foucault 1991; Rogers 2012) and to engineer consent (Bernays 1947). Stuart Kirsch (2014) uses the term corporate social technologies to include companies' ability to adapt to pressure from critics, promote uncertainty and doubt in order to establish consent, as well as to manipulate scientific research. The way we use the concept, however, is based on a longer trajectory of literature dealing with corporate techniques to use both coercive power as well as softer and "quieter registers of power" (Allen 2003; Frederiksen and Himley 2019), sometimes referred to as corporate counterinsurgency (Dunlap and Fairhead 2014; Dunlap 2020) or corporate security technologies (Jakobsen 2020). Further, as Bebbington (2010) maintains, one of the most important effects of social responsibility programs "is to close down public debate" (p. 107).

${ }^{5}$ The current use of CSR principles is the product of John Ruggie's work for the UN working group on business and human rights (Ruggie 2007). Prior to Ruggie, Bowen (1953) is seen as the first to outline CSR in his early work titled Social Responsibilities of the Businessman. 
Corporate industrial projects are often affirmed through the consultation process and can intensify social and ecological impacts. While consultations fall into the soft category of corporate strategies, they often happen in a context of hard and violent land grabs (Machado et al. 2017; McNeish 2017; Le Billon, Roa-García and López-Granada 2020). Jennifer Franco (2014) points to the increasing use of Free, Prior and Informed Consent (FPIC) as a tool to facilitate and legitimate large-scale land grabbing. Similarly, Alexander Dunlap (2018) argues that the FPIC procedure was "an attempt to channel rebellious tensions into 'constructive' negotiations and 'appropriate' channels...mediated by a bureaucratic procedure" in his research on a wind energy consultation process in Juchitán, Mexico (p. 91). Consultation processes and the resulting compensation payments often legitimize land acquisition and further extraction.

Almut Schilling-Vacaflor and Jessika Eicher (2017: 1457) shed light on the exclusionary "carrot-andstick" techniques in consultations and compensation negotiations, demonstrating how divide-and-rule tactics are used by the state and extraction corporations alike, exacerbating local conflicts and dividing communities (see also Bebbington 2012; Pellegrini and Arismendi 2012; Flemmer and Schilling-Vacaflor 2016). Proponents of compensation have argued that compensations function well when the correct monetary formula is applied (McLeod 2000; Hilson 2002). Indeed, many economists and business academics seek ways to formulate compensation programs into a corporate accounting framework. McLeod (2000), for example, outlines an economic calculus that includes sociocultural losses and argues that compensations can be used to reduce conflict. However, research on compensation programs finds that they are often inadequate and that communities are rarely satisfied (Hilson 2002; Spash and Aslaksen 2015; Schilling-Vacaflor and Eichler 2017; Ballet, Lompo, and Randrianalijaona 2019). Compensation can take the form of payments, resettlement and/or various types of environmental, social and education projects.

Compensations often fail because of conflicting legal claims to land and, therefore, are asymmetrically rewarded, leading to more conflicts within and between communities (Kidido et al. 2015; Adonteng-Kissi 2017). Additionally, the damage done to nature, culture and place caused by large-scale extractive industries is incommensurable with compensation payments. Martinez-Alier (2001) examines the clash of valuation discourse that goes beyond the limits of cost-benefit analyses to take into account Indigenous territorial rights, environmental racism, and security. Communities often legitimately use language that goes beyond the simplistic financial measurements of conventional economics. Fleisher Trainor (2006) argues that it is essential to acknowledge the varying realms of value, including cultural, geographic and spiritual expressions of value. To determine compensation, corporations use a strict utilitarian accounting system grounded in Western economics as the means to justify a system that values accumulation over natural and human resources. Fabiana $\mathrm{Li}$ (2011) calls this the "logic of equivalence", defined as an attempt to equate the damage from a mining project with social and ecological compensation through the same value system. She argues that agreements on compensation can be ways to "buy compliance, with little regard as to whether it would actually compensate for the mine's potential damages" (p. 68).

Understanding that the reductionist notion of economic valorization over all other values can lead to increased inequalities, this article asks how compensations are used as a mechanism that has created more discord and inequality than benefit for communities impacted by coal mining in La Guajira. This article examines the incommensurability of compensations based on field research with impacted community leaders. Although local communities are greatly impacted by mining operations and require social support - and may eventually receive the long-awaited and incommensurable one-time compensation - we find that compensation projects act primarily to further extractive industry operations and are best understood as social technologies that benefit the corporation more than the affected local population.

\section{Regional and cultural background}

Geographically, La Guajira is divided into the Upper (Alta), Middle (Media), and Southern (Baja) Guajira. The Upper Guajira is a semi-desert region where the Cerrejón coal port, Puerto Bolivar, meets the end of a 150-kilometer railway that transports coal from the mines (Figure 1) located in the south. While much of the Middle Guajira region is semi-arid and lacking in ground water, its southern portion consists of a dry tropical 
forest, one of the most endangered ecosystems in Colombia. The mining pits are located in (or bordering) the Baja Guajira, where there is more arable land, green vegetation, wildlife, and rivers.

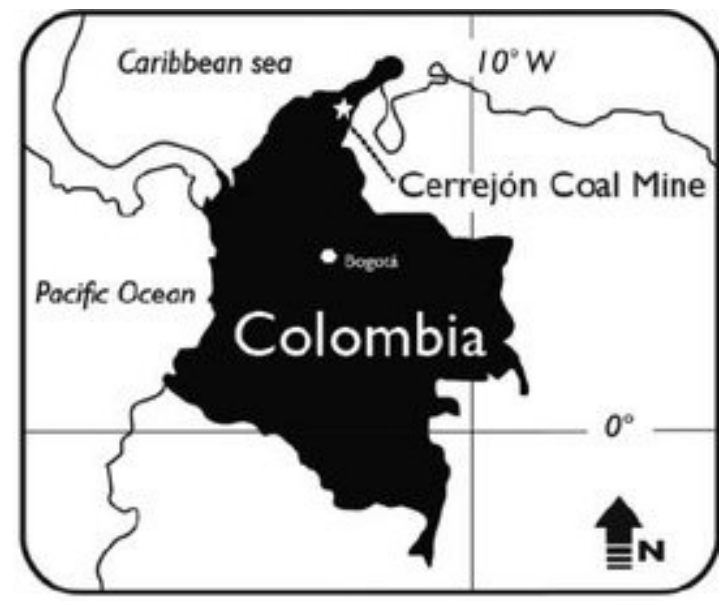

Figure 1. Location map. Source: DOI: 10.1080/14772019.2011.569031

The Wayúu, Colombia's largest Indigenous group, comprise approximately $46 \%$ of the population of La Guajira (DANE 2019b), and their presence in the area dates back more than three thousand years (Fajardo Gómez 2007). La Guajira ranks as Colombia's second most impoverished department, ${ }^{6}$ with $53.7 \%$ of the population living below the poverty line and $26.7 \%$ living in extreme poverty (DANE 2019a).

Since the early 1980s, coal mining in La Guajira has been linked to the displacement of the Indigenous Wayúu, Afro-Colombian and campesino communities. Prior to Cerrejón's arrival, the Wayúu had resisted settler colonialism, maintaining a distinctive culture and a large degree of autonomy (Hernandez 1983). Wayúu pastoral villages cultivated corn, beans, and other fruits and vegetables (personal communication March 2019). The Wayúu also foraged for medicinal plants and wild foods such as mamón (Spanish limes) and guaimaro.7

In 1991, Indigenous Wayúu anthropologist Weildler Guerra Curvelo described how Cerrejón had already caused severe harm to Wayúu communities, despite the occasional one-time contributions it gave the local inhabitants to address specific, immediate needs (Curvelo 1991: 49-52). The Wayúu have very different perceptions of compensation, as Curvelo (2002) documents in his ethnographic account of conflict resolution among the Wayúu. The normative rules around how to settle a conflict with an agreed-upon form of compensation are established within a Wayúu law that is passed down through spoken-word and mediated by a pütchipü'ü ${ }^{8}$ (Polo Figueroa 2017). Typically, the victim family requests a certain amount of materials (including necklaces, animals and other valuables) based on the severity of the offense. A death, for example, is the highest offense and can result in a family giving up all of their valuables to the family of the victim (personal communications March, May, June 2019).

In one example of a culture clash in dealing with compensation, animals are struck by Cerrejón's coal train on a daily basis, a loss that has usually gone uncompensated. When the company does repay families for their lost livestock, it often does so outside of the normative Wayúu rules of compensation, as one community leader noted:

\footnotetext{
${ }^{6}$ The term "department" in Colombia refers to a legally demarcated region like a state or a province.

${ }^{7}$ Guaimaro is a drought resistant tree that bears a highly nutritious fruit that was an important food source among many Wayúu communities.

${ }^{8}$ Pütchipü'ü is the Wayúunaiki word for a traditional Wayúu mediator, also referred to in Spanish as a palabrero.
} 
According to our laws, if you kill my animal or rob me of an animal, you give me five or what I ask. Because if it is a female animal, it is more than losing one animal, you're losing the potential offspring. But when the train kills a goat, they replace the goat with just one and it can take three to four months when they should be returning the animal immediately. These are things that they are violating... for Cerrejón, our culture does not exist. (Personal communication January 2019)

Compensation under customary Wayúu practice is settled when the impacted person or persons determine the process to be resolved. This is a mediated conflict-resolution process that dates back thousands of years and is a keystone cultural practice that serves to settle grievances in a peaceful way. Under multinational Western corporate practices, Cerrejón follows consultation and compensation practices that have been established based on their interests and mandated by the state, but these processes fall short in addressing ongoing grievances and frequently violate the cultural practices of the Wayúu.

\section{Data collection}

Qualitative data collection was conducted in 2018 and 2019. One of the authors conducted her initial research in January and February 2018, and continued from October 2018 to May 2019, totaling 10 months. Another author was in the field from February to May 2018 and again from July 2018 to June 2019 in the departments of La Guajira, Magdalena and Cesar, totaling 15 months. The third author made an initial visit to La Guajira in August of 2018 and returned to the field from December to July of 2019, totaling eight months. The three authors frequently collaborated on field research in La Guajira between January and June of 2019. This article is the product of their joint research.

Non-probability convenience and snowball sampling were used. The authors conducted semi-structured interviews with 107 participants, among whom were Indigenous Wayúu and Afro-Colombian communities impacted by coal mining, current and former Cerrejón employees, state officials, and corporate representatives. Research with community participants occurred in both rural and urban settings. Interviews ranging from 30 to 90 minutes were conducted in peoples' homes, in restaurants, offices, public spaces, community centers and other locations that were decided on by the participant. Care was taken to maintain participants' safety and anonymity. Participants gave oral or written consent at the beginning of each interview. When agreed, interviews were audio recorded. Participants received no financial compensation for their participation.

Additional qualitative data were generated through direct and participatory observation in various settings, including: ten meetings specifically related to prior consultation or compensation with representatives of Cerrejón, state officials and community members; fifteen Wayúu villages, four Afro-Colombian communities, and six other communities; and at Cerrejón's mining operation, railroad, and port. Community visits included multiple overnights in nine Wayúu villages, where the authors gained a deeper understanding of Wayúu culture and of the challenges they faced related to mining. The authors also attended relevant public events and academic, corporate and NGO conferences, where field notes were taken. Participant observation allowed the authors to generate thick description from field notes to construct a narrative account (Fetterman 2010). Field notes were written and securely shared between the authors throughout their joint field work between February and June 2019.

In the following Section, we will outline pertinent Colombian laws that support a wider understanding of the legal framework in which Cerrejón and impacted communities operate.

\section{The legal framework of corporate compensations for impacts and consultations}

Colombia's current constitution of 1991 is recognized for its broad acknowledgment of the rights of Indigenous Peoples. Praised for being "the ecological Constitution", it contains 34 articles related to the protection of the environment (Macías Gómez 2020). Law 99, issued in 1993, defines the institutional framework for environmental protection and management of natural resources. In addition to requiring that mining companies obtain an environmental license, this law created the Ministry of Environment (now called 
the Ministry of Environment and Sustainable Development), which oversees environmental policies at the national level.

The National Environmental Licensing Agency (ANLA) ${ }^{9}$ created in 2011 with the passing of Law 3573, is the administrative entity issuing and evaluating environmental licenses. An environmental management plan is a prerequisite for obtaining an environmental license, required for any mining project in Colombia. The environmental management plan, which includes an impact assessment, loosely defines the methods of compensation for environmental damage and loss of biodiversity (Ministerio de Ambiente y Desarrollo Sostenible 2012: 2015). ${ }^{10}$

The licensing system has weaknesses. It relies on information provided by the companies themselves (Cabrera Leal and Fierro Morales 2013: 114). It has been documented that extractive corporations have largely coopted national environmental agencies and governmental authorities through pressure and threats from business organizations to impose their interests, with classic warnings like "without us, there is no future" (Pardo 2018: 5), as well as direct capture of the different branches of public power through influencing national, regional and local political elections (ibid.). Furthermore, experts and researchers point to strategies such as lobbying, which among other things facilitated a tax policy written to reduce the tax burden to companies via exemptions and deductions and a mining code that favors interests of transnational companies (ibid.; Strambo et al. 2020: 4). Similar to Strambo et al.'s (2020) overall findings, lawyers in Bogota explained to us how ANLA's staff reductions, lax evaluation of environmental impact assessments, and the flexibility of compensation program design leave room for maneuverability, interpretation and political negotiation between the company and ANLA regarding the degree and manner of compensation (personal communications February 2019; May 2019 and April 2020).

The Environmental Impact Statement-Social Impact Statement (EIS-SIS) for the coal mining project in La Guajira that is now known as Cerrejón ${ }^{11}$, was prepared in 1982 as the basis for the environmental license. Therefore, it was evaluated based not on the current legal and regulatory frameworks described above, but rather on a much weaker 1974 environmental protection law which remained valid until 1993 (Calderón, Prada, and Loyo 2013: 45). Although Cerrejon's original impact assessment ran to six volumes, the local indigenous populations were barely considered, and no socio-cultural variables received mention. ${ }^{12}$ Moreover, the study was completed in February 1982, after the road from the mine to Puerto Bolivar was complete and many indigenous families displaced (Curvelo 1991).

Over the past 37 years, more than 60 modifications have been appended to Cerrejón's original environmental license. ${ }^{13}$ Cerrejón was never legally obligated to revise the 1982 impact assessment, which led to questioning the corporation's license (CAJAR 2019). The Bogotá-based lawyer's collective CAJAR examined the license and its modifications, finding significant falsehoods and omissions of information by which Cerrejón was able to manipulate its approval. Based on this assessment, CAJAR, NGOs and communities affected by the mine, filed a legal action of nullity (acción de nulidad) in February 2019. This action seeks to declare the authorization of the entire operation invalid (ibid.). As we write, the case is in the courts and a ruling is pending. At the same time, to comply with the 2016 Constitutional Court ruling (T-704) expanded upon below, Cerrejón's environmental impact assessment must be evaluated based on input from the communities affected by the mine.

\footnotetext{
${ }^{9}$ The Spanish acronym stands for Agencia Nacional de Licencias Ambientales.

10 This is to be measured according to the 1517 resolution, from August 31, 2012, entitled "Manual for Assigning Compensations for the Loss of Biodiversity" and "Manual de Compensaciones del Componente Biótico." Since 2018, a Social Management Plan detailing the company's plan to prevent, mitigate and compensate for any social impacts is also required in order to obtain a mining concession (ANM 2018).

${ }^{11}$ The original mining concession was a joint venture between Carbocol (a Colombian state-owned company) and Intercor (a subsidiary of the US-based company Exxon).

${ }^{12}$ In impact assessments from that time, managing these issues was not mandatory. However, the fact that it was noted then by both anthropologists and the contracted company is noteworthy.

13 The license, "LAM 1094 of Carbones del Cerrejón," was originally issued by INDERENA in Resolution 797 of 1983.
} 
The 1991 Constitution, the tutela, and consulta previa

As indicated in the introduction, the T-704/2016 ruling is the result of a tutela action. ${ }^{14}$ The tutela is part of the state's ordinary judicial channels to address remedial requests and enables any person or group of individuals whose fundamental rights are being threatened or violated under Colombian Constitutional law to request that a judge with territorial jurisdiction protect that petitioner's rights. Fundamental rights guaranteed by Article 86 of the 1991 Constitution include the rights to education, health, and political and socio-economic freedoms. The tutela is perhaps the most important of the special rights granted in the 1991 Constitution.

Prior consultation is another feature of the 1991 Constitution (Law 21), introduced through the ratification of the ILO convention 169 on Free, Prior and Informed Consent (FPIC) for Indigenous peoples (ILO 1989). FPIC requires a non-coercive consultation negotiation prior to any development intervention, in which full and accurate information about the proposed project and its implications is provided in order to ultimately establish consent from the affected communities. Our review of the literature on indigenous participation in FPIC processes shows, however, that the actual processes are seldom prior, informed or free. In Colombia, a tutela is often made in response to violations of the right to prior consultation, as we will illustrate.

In the case of Cerrejón, FPIC was not an upheld policy when the environmental license was initially issued, and indigenous peoples generally had limited legal protection. Any damage that has been done or will be done is, therefore, often dealt with ex post facto. ${ }^{15}$ Since compensations for the negative impacts of mining depend on the multiple interpretations of the impact assessment, the process is subject to politicized negotiation. Our research sheds doubt on the possibility of compensating through a system dominated by a monetary logic of equivalence (Li 2011). Finally, we critique the ways in which negotiations around compensations take place, setting the stage for negative social consequences and outcomes.

\section{Case studies}

Three cases of compensation with communities in Cerrejón's zone of influence serve to highlight areas of concern implicit in compensation and consultation processes. The first example deals with Cerrejón's diversion of the Arroyo Bruno. ${ }^{16}$ This case demonstrates the inadequacy of compensations to repair damage done by severe degradation of the riverine and arboreal environments and consequent disruption of cultural and spiritual practices. The second case focuses on a specific compensation deal negotiated between Cerrejón and a Wayúu community located next to one of the coal pits. This case exemplifies how compensation processes can sow divisions that leave a community weaker after receiving a compensation than it was before engaging with the corporation. Finally, we examine the aforementioned Constitutional Court ruling T-704/2016, which mandates that Cerrejón carry out post consulta previa ${ }^{17}$ (post prior consultation) with all communities within the zone of influence. We argue that, rather than repairing damages in impacted communities, this process effectively legalizes Cerrejón's project and suppresses opposition to the mine throughout La Guajira.

\section{Case 1: The Arroyo Bruno diversion: a threat to water, territory, and dreams}

La Guajira is Colombia's most water scarce region. Potable water with 24-hour accessibility exists in just two places on the peninsula: Mushaisa, Cerrejón's gated community near the mines where only the upper management can live, and another employee compound adjacent to Puerto Bolivar. ${ }^{18}$ The Media and Baja Guajira contain a delicate dry tropical forest ecosystem whose critical water resources are threatened by extractive industries, deforestation in advance of mining, and climate change (Ulloa 2020).

\footnotetext{
${ }^{14}$ A tutela can best be translated as a plaintiff or protection measure reviewed by the Constitutional Court of Colombia.

${ }^{15}$ A law that retroactively changes the legal consequences (or status) of actions that were committed, or relationships that existed, before the enactment of the law.

${ }^{16}$ Arroyo is Spanish for stream.

${ }^{17}$ Because this type of consultation is to occur decades after the project was initiated, associated compensations should address damages incurred throughout the project's entire operation.

${ }^{18}$ Cerrejón installed and continues to manage a desalination plant at Puerto Bolivar.
} 
Cerrejón's 69,000-hectare concession sits atop the region's largest alluvial aquifers (Cerrejón 2017: 5). Its massive open pit mines impact several rivers, among them the Ranchería River, the peninsula's principal water source. The mining operation demands an exorbitant amount of water. In 2017, the mine used at least 13 billion liters of water, 1.1 billion of which was pumped from the Ranchería River and its aquifer (ibid.: 59). ${ }^{19}$ Community members report that Cerrejón has "killed" at least seventeen rivers and streams (authors' fieldnotes April 2019).

Cerrejón has continued to expand its mining area, affecting the hydrology of the entire region. The company's modification of the Arroyo Bruno, a significant tributary that feeds the Ranchería River, led to widespread regional, national, and international opposition. In 2016, Cerrejón completed the construction of a 3.6-kilometer artificial channel that diverts the Bruno away from the La Puente Pit to allow the company to begin extraction of over 35 million tons of coal from underneath the natural riverbed (Banks 2017). Information about this project on Cerrejón's website states that the diversion involved state-of-the-art engineering technology, eliciting international praise from biologists, geologists and engineers. Carlos Vargas of the National University is quoted stating, "This project is a natural laboratory that should be shown to the world" (Cerrejon n.d.). Community members who rely on the Arroyo Bruno for their survival tell a different story. The La Puente project affects more than a dozen Wayúu villages and several Afro-Colombian communities who can no longer access this section of the Bruno, on which they depended for domestic water use, fishing, and irrigation. In addition, water security for over 200,000 Guajiros living throughout the region is threatened because the Arroyo Bruno provides water to rural and urban areas via water trucks (observation at meeting April 2019). Displacement of communities for the construction of the diversion took several forms; Cerrejón purchased land from farmers and vulnerable Wayúu families and, in at least one instance, seized a family's farm (observation from fieldnotes July 2019; personal communication April 2020).

When one of the authors toured the La Puente project with legal representatives of impacted communities as part of a court-ordered verification visit, she observed a dry riverbed that is several times wider than the natural channel and exposed to the hot sun. Small trees planted along the edge provided no shade, contrary to the original channel, which was bordered by mature, tall trees providing a canopy that was once home to monkeys and migratory birds. Based on participatory observation at public forums, Cerrejón maintains that the modification has in no way compromised the integrity of the water source, claiming that the Bruno is a seasonal river that dries up periodically (Cerrejon n.d). Locals contest this, insisting instead that it is coal mining that has altered the region's hydrology. Their claim is backed by government data compiled and analyzed by the Bogota-based organization Terrae (observation from fieldnotes July 2019). In a recent study on the controversy of this diversion project, Carmona and Jaramillo (2020) conclude that Cerrejón "worked to disqualify activist concerns as being laden with affects, hiding individual interests, and without sufficient technical substance" by framing the risks associated with the project as specific types of "acceptable risks", all to be managed based on scientific engineering technology (p. 7).

Cerrejón now has mining rights to at least four kilometers of the land on both sides of the $3.6 \mathrm{~km}$ artificial channel. This section of the Bruno is now inaccessible to at least five nearby Wayúu villages. One Wayúu woman explained: "[Cerrejón] said they would replicate everything, but it was a lie. Anamuc, ${ }^{20}$ Guaimaro... Do you know the amount of medicinal plants and trees with food that we used to eat? And you go there now, they are gone... The number of animals has changed too. Before, it was easy to hunt a rabbit for example, but now there are not any" (personal communication January 2019).

The river also has an irreplaceable spiritual significance for the Wayúu, who believe that dreams are a crucial source of revelatory information about their health and wellbeing (Watson 1981; personal communications 2019; Perrin 1995). ${ }^{21}$ A Wayúu community leader whose village was cut off from the Bruno

\footnotetext{
${ }^{19}$ Water use research conducted by one of the authors among five communities suggests that locals have access to between two and fifty liters of water per person per day (personal communication 2019).

${ }^{20}$ Anamuc (Petiveria alliacea) is a native plant whose roots are ground and mixed with lemon and water to produce a medicine that Wayúu use to treat many sicknesses, including colds and flus.

${ }^{21}$ One of the authors conducted structured and semi structured interviews with eighteen Wayúu individuals on the topic of dreaming.
} 
recalled that, "The Arroyo Bruno for us was a fundamental part of our lives because we would go to fish and forage for food from the trees along the river. Sometimes my mom would dream that we would go to the river and bathe in it at midnight or two in the morning, so we would have to go there" (personal communication February 2019). The Wayúu believe that after a bad dream, bathing in cold water, especially river water, will protect the dreamer and their family from danger (personal communications March, April, June 2019). ${ }^{22}$ When asked how cultural damages could be compensated, a Wayúu leader replied:

There is no formula or law. We can ask for land, animals, necklaces, many things, but this will never compensate for the loss of a dream. How could it? This dream is not going to return. It has already been lost... The problem remains, the pain, the suffering, the sadness in the family or the community... Our dreams guide us away from danger. (personal communication April 2019)

Numerous interviewees who had engaged in negotiations with Cerrejón reported that the company tries to compensate a community by offering a one-time sum of money to each family. However, in group interviews with five resettled communities, we found that one-time payments were quickly spent on necessities. One Wayúu village located alongside the Arroyo Bruno, having witnessed how the consultation and compensation process had left other communities worse off, resolved to protect the river rather than accept money in exchange for their land. One Wayúu man from this village told us:

How will it serve me to do this consultation when I will not really benefit from it? Because yes, I might get a bit of money, but this money is not enough to be able to buy all of what I just sold. ... for them everything is money... [the company says] 'we will buy this from you so that you can live nicely somewhere else... We will send you to a town, to Albania, where you will have permanent water provision, electricity, a paradise...' But here, this is paradise for me... Yes, money is nice, it gives us the possibility to buy stuff, perhaps a bit of momentary happiness, but it would give us more enemies than happiness. (Personal communication March 2019)

These local experiences highlight the incommensurability of monetary compensation with the loss of water, ecosystems, and the ability to maintain cultural practices related to the river. Another problem with compensation and consultation is its tendency to benefit some and exclude or harm others, producing "more enemies than happiness." In the case of the Arroyo Bruno diversion, initially only one Wayúu community was consulted. This community resides along the Ranchería River downstream from its junction with the Bruno's original channel. This created confusion and skepticism because the consulted community was not located directly alongside the Bruno, and other communities that would be more severely impacted were not originally consulted. Cerrejón was later legally ordered to consult three other Wayúu villages, including one that had been displaced when the company acquired land near the Arroyo Bruno.

The methodology used by the company and the Ministry of the Interior to decide who should be consulted and compensated is questionable. When Cerrejón first proposed the diversion, the Ministry of the Interior and the company denied the existence of Wayúu communities in the impact zone. A Wayúu leader in an affected village told us that many had suspected that Cerrejón pressured authorities in Bogotá to declare that the community originally consulted was the only indigenous community that would be impacted. When one of the authors brought this concern to a former official of the Ministry of the Interior and the Ministry of the Environment, he replied, "Yes, it would not surprise me, that is probably what happened" (personal communication July 2019). As such, our research concurs with Kirsch's (2014) findings regarding the numerous ways extractive corporations and states deny the impacts of mining on indigenous peoples. Companies manage to do this, he explains, by invoking different forms of corporate technologies to create doubt, manipulate science and use what he calls the "politics of time" to delay the recognition of eventual impacts (148).

\footnotetext{
22 See Watson (1981) for in-depth discussion of Wayúu dream theory and its ontological and epistemological bases.
} 
When companies arrange consultation with only a (strategically) selected number of communities, or specific members of that community, corporations can publicize so-called successful consultations, improving the company's image by highlighting cooperation with local communities. Certain communities or initiatives are used strategically as staging grounds for legal verifications and visits from shareholders, government agency representatives, and human rights organizations. Importantly as well, the compensation for one community and lack of consultation with others contributed to distrust and division between communities.

When three Wayúu communities filed a tutela in 2016 to contest the diversion project, the Constitutional Court ordered that the grave inadequacies of the licensing process with respect to the environmental, social and cultural impacts of the diversion should be resolved by an interinstitutional roundtable. The first roundtable meeting on the Arroyo Bruno project included the plaintiffs of the tutela and other community leaders. Cerrejón's collusion with government representatives became overt when the meeting's moderator, a lawyer from the Ministry of the Environment, called for a recess so the state and corporate representatives could convene among themselves. During the break, the moderator coached Cerrejón's representatives, suggesting strategies to ensure the result they sought (personal observation February 2019). Throughout our fieldwork, many participants candidly spoke of the special relationship between Cerrejón and state officials. A Wayúu leader living next to the Bruno remarked, "I'll say that they are complicit...they are both one...The state is selling us and enslaving us to them" (personal communication March 2018).

The Arroyo Bruno's diversion serves to illustrate how compensations are incommensurable, in that they cannot possibly address the environmental, cultural, and spiritual damages suffered by local communities. The loss of the Bruno degrades the way of life of river-dependent communities and threatens the water security for all of La Guajira. This case study is an example of state-supported corporate violations of the fundamental rights of indigenous communities to prior consultation and to a healthy environment as elaborated in the Colombian Constitution. The one-time payment does not compensate the cultural and financial impacts, nor does it generate sufficient wealth to secure communities against poverty and the loss of food sovereignty. The following Section will look more closely at a particular community's experience with negotiating a compensation deal with Cerrejón.

\section{Case 2: Provincial's "bad deal"}

In 2016, Provincial, a Wayúu resguardo ${ }^{23}$ located on the Ranchería River just two kilometers from Cerrejón's Patilla coal pit, entered into a negotiation with Cerrejón over a compensation package. Some residents of Provincial call what resulted el mal acuerdo or "the bad deal." This case shows how compensations can divide communities, making them more vulnerable to future interactions with the powerful multinational corporation and the state that backs it.

Provincial's 470-hectare territory is home to over 700 people who are distributed across six sections and represented by an elected cabildo (chief). Traditionally, Wayúu families in Provincial lived by fishing, hunting and gathering, pastoralism, and agriculture. Few families are now able to farm due to inconsistent water access, drought, rising temperatures, and the ubiquitous coal dust, which interferes with crop production. Hunting and fishing are no longer reliable sources of food, locals say, because the mine has depleted wildlife and compromised the health of the river.

Provincial residents told us that two of the worst problems caused by the corporation are constant noise and air pollution. Polvillo (coal dust) carried by the wind from the Patilla pit can be seen on rooftops and fence posts. Many children suffer from respiratory and skin conditions caused by coal dust, which has led to some Wayúu women successfully bringing legal cases against Cerrejón (Rojas-Páez 2017). As the authors witnessed during several overnights in the resguardo, the scheduled afternoon explosions and around-the-clock noise of giant machinery replace the sounds of nature and serve as a constant reminder that the mine is encroaching on their ancestral lands.

\footnotetext{
${ }^{23}$ An indigenous reservation recognized by the state. Resolución 085 officially recognized Provincial in 1988.
} 
Cerrejón now owns land to the north, west, and south of Provincial. Forests where the Wayúu once hunted and foraged are now off limits and surveilled by guards who bar access to the land on the far side of the Ranchería River. One resident stated:

Provincial was free. I used to go walking from here and I went where my feet took me, no one told me I could not. Now, you walk through the woods and you find a guarda bosque (forest guard) and they ask what you are doing, where you are going. Now you cannot go in the river or cultivate near the river. Both sides are controlled by Cerrejón. The multinational is pegado al resguardo (stuck to the reservation). (Personal communication July 2019)

In 2011, Cerrejón approached Provincial for a prior consultation when it was planning an expansion named the Iwoya project, which would entail a $26.5 \mathrm{~km}$ diversion of the Ranchería River in order to extract 500 million tons of coal from beneath the riverbed. At this time, Provincial was united around the struggle to protect the river, helping to lead the opposition to the project along with numerous national and international organizations and journalists. A community leader explained that Provincial had "paralyzed the relationship with the company for six years during which we had no contact... Cerrejón called us once in a while to change our minds, but we always said no, and internally in the community we had weekly meetings where we made sure to stand strong in our position against Cerrejón" (personal communication March 2018). The company decided not to divert the river, claiming to have based this decision on a drop in the price of coal rather than on the international, national and local mobilization in support of the Wayúu and the river (BNamericas 2012).

Provincial launched a legal claim against Cerrejón in 2016. With assistance from CAJAR, they sought compensation for all of the damages that had occurred since the 1980s. Cerrejón, eager to settle the case outside of court, offered to sit down with Provincial's leaders, insisting that a legal demand could take a long time to be resolved and that compensation would arrive more quickly through direct negotiation. The community-initiated talks with the corporation and closed the deal by the end of the year. A leading figure, considered by some today to be on the side of Cerrejón, explained:

In 2016 we established a mesa de diálogo (roundtable negotiation) with Cerrejón, consisting of six people from here. We asked for an area for our animal rearing and Cerrejón was willing to give us this...Ten families benefit from this as compensation. We are 170 families. [...] After the demanda (claim), an agreement was signed based on the negotiation of the land. We also got nine university seats, there has been some kind of project, and they got thirty pigs for the farm, meaning that when for example someone from the community dies, they can use one of the pigs for the funeral... The road was [fixed] a year ago. It was completely inaccessible before. Also, the aqueduct system is going to be fixed, before we had no water in the houses. We got new pumps. (Personal communication March 2019)

According to another resident who opposed the conditions of the agreement, only three leaders closed the deal after holding private meetings held in Bogotá, without the legal representatives from CAJAR. The other participants in the mesa de diálogo dropped out because they did not agree with Cerrejón's terms (personal communication July 2019).

In 2017, Cerrejón purchased 640 hectares of farmland in the Cerranía del Perija for the community; awarded nine scholarships for college; and installed coal dust protectors on one hundred homes made of barro (adobe) (personal communication April 2019). The farmland is ninety minutes from Provincial by car, a luxury few in the community can afford. Therefore, most families have been unable to use their parcels and some have sold them (personal communication July 2019). Many residents are unhappy with the outcome of the negotiation. A group of mothers has been explicit in their resistance to the deal because they argue that it does not address the consequences of coal mining on the health of residents in any meaningful way. The coal dust protectors, they say, do not prevent coal dust from entering the home; and besides, the Wayúu spend most of 
their time outside, oftentimes sleeping in hammocks under open air structures, experiencing constant exposure to airborne coal particulates.

In benefitting only a small number of families in Provincial, the "mal acuerdo" created irreparable social divisions. Some community members believe that the leaders who negotiated on behalf of the community received a special deal, noting how their attitude towards Cerrejón changed from one day to the next. One resident stated, "Unfortunately, the company started to divide [the community]. They signed a bad agreement...The magical art of Cerrejón is to divide" (personal communication April 2019). The divisions were, by some accounts, the worst impact that Cerrejón has had on the community.

Three years after receiving compensation, many Provincial residents report being no better off than they were when they decided to deal directly with Cerrejón. The scholarships and compensated land have only partially benefited the community. The resguardo remains without a reliable water source, and many families struggle daily with food insecurity. Children continue to suffer from respiratory illnesses and skin rashes. Adults are underemployed and unable to farm, fish, or forage. The Ranchería river remains polluted with industrial waste. ${ }^{24}$ As one Wayúu woman stated, Provincial's "cultural process has been broken by the mine" (personal communication April 2019). As a result, Provincial is more divided than ever because the negotiation process for compensation has weakened the cultural and social ties within the community.

\section{Case 3: Media Luna Dos and the T-704/2016 ruling}

In 2016 Cerrejón requested approval from ANLA to expand the Bolivar coal port without consulting any surrounding communities. ${ }^{25}$ Previously, in November 2013, the Ministry of the Interior certified that "ethnic communities" did not exist within the zone of influence of the port after its representatives made a verification visit (Corte Constitucional 2016). When locals petitioned ANLA to confirm the presence of Wayúu living near the port, ANLA responded saying that this was within the purview of the Ministry of the Interior, which had already ruled that no such ethnic communities existed. Manipulation of research, denial of facts, and promotion of uncertainty are all forms of corporate social technologies. This Section will explore how the company's management of the situation can be understood as part of their social technologies that ultimately create further divisions and weaken opposition, thereby furthering extraction.

A social standards manager of Cerrejón explained in an interview with one of the authors in early 2018, that the "regretful error...[of not] being aware of" the company's impact on indigenous communities ended up having negative consequences on the company's legal obligations. According to her, the Ministry of the Interior had twice stated that Cerrejón "did not need to do prior consultation because there would be no impacts [on indigenous communities]" (personal communication February 2018). In the end, some of the planned port expansion was delayed until Cerrejón conducted further consultations with Media Luna Dos.

Responding to the Ministry's and the company's denial of the existence of Wayúu communities near Puerto Bolivar (and, therefore, of their constitutional right to a prior consultation), a Wayúu leader from the community Media Luna Dos brought a tutela to the Constitutional Court. Much to everyone's surprise, the case succeeded. ${ }^{26}$ The ruling, known as the T-704/2016, expanded the scope of the case to affirm the right of all communities in the zone of influence (from the port to the mine) to a "post-prior consultation" and compensation for damages. ${ }^{27}$ In other words, what started as one tutela intended to address a specific case resulted in a historic ruling that required Cerrejón to analyze its impacts throughout the region.

\footnotetext{
${ }^{24}$ One of the authors piloted a small water study in several communities in the impact zone of Cerrejón in July 2019. A sample she took from the Ranchería River next to Provincial was tested in a certified laboratory for 32 parameters, revealing a level of mercury contamination 70 times the recommended limit. See the full results: https://londonminingnetwork.org/2019/11/mercury-in-vital-water-source-in-colombian-region-of-la-guajira/

${ }^{25}$ Cerrejón proposed to 1 ) enlarge the dredged channel that allows boats to access the port, 2) to construct a new pier, and 3) expand the desalination plant.

${ }^{26}$ The case lost in the second instance but was chosen for reconsideration and revised by another judge.

${ }^{27}$ According to an assisting Wayúu lawyer, the number of communities that should be included in this consultation process is 300 (personal communication February 2019).
} 
The Constitutional Court demanded 1) the suspension of the planned expansion of the port until the company consulted the impacted communities; 2) acknowledgment of Media Luna Dos's fundamental right to consultation; and 3) re-evaluation of the environmental license, ${ }^{28}$ including an assessment of whether the Comprehensive Environmental Management Plan for Cerrejón's entire mining operation is adequate to manage the pollution the operation generates (Corte Constitucional 2016). The active participation of the entire affected population in the zone of influence should be guaranteed. Since indigenous populations were involved, consultations should be done in accordance with the rules of FPIC. Lastly, the ruling ordered Cerrejón to implement an immediate plan to mitigate and compensate for environmental, social, and cultural damages. Negotiations for these compensations must be carried out with the participation of the affected communities (ibid.).

After this landmark ruling, traditional Wayúu leaders of Media Luna Dos and their legal representatives began the consultation negotiation with Cerrejón, resulting in a compensation of fifteen equipped fishing boats given to fifteen traditional Wayúu leaders. ${ }^{29}$ However, when we asked a group of Media Luna Dos residents how this benefited the community, one man responded, "It has not really helped us... There are no fish because of the port!" (personal communication March 2019). ${ }^{30}$ Cerrejón's version of the story is that the fifteen boats were a "gift" given to the community as part of a sustainability project to "help conduct sustainable fishing and mitigate overfishing." ${ }^{31}$ In reality, the coal dust and marine traffic at the massive port has caused fish populations to decline, having a devastating effect on marine ecology so that fewer people live from fishing today than before Cerrejón's arrival. Many Wayúu from this area have had to leave in order to make a living and among those who remain, rates of child malnutrition and mortality are alarmingly high (Posada 2020).

Thirty years of coal dust contamination and reduction of territory have destroyed the Wayúu's traditional subsistence economy and, with it, much of the more intangible but deeply rooted dimensions of their culture. Compensation in Media Luna Dos did far more to provoke internal conflict than to ensure food sovereignty. One resident told us that his family received three of the fishing boats. Awarding compensation to some individuals and not to others led to resentment and schisms within and between communities. It is an open secret that Media Luna Dos is divided in two: those who closed the deal with Cerrejón, and those who still await eventual recognition and compensation. The company engineered what one Wayúu leader called a "campaña de presticio" (prestige campaign). According to his perception, the company managed to make leaders from different parts of the community indirectly fight each other for "prestige" by, in his words, "blocking their minds with pocket money" (bloquear mente de autoridades con lo del bolsillo) (personal communication March 2019). Cerrejón has managed to use the far-reaching ruling as an opportunity, adjusting the process as much as possible to its own favor, in part by taking advantage of the fact that it is usually negotiating with communities lacking basic resources. The compensation package of fifteen fishing boats is incommensurate with the complex economic, social and cultural impacts caused by the coal port and sets a low bar for other communities still awaiting consultation.

The T-704/2016 ruling was seen by some as a victory for the mining-impacted communities. For the Wayúu rancherías alongside the rail line, it might be the only time families receive any compensation from Cerrejón. A Wayúu leader who serves as a legal advisor to various communities in the consultation process noted both the achievement and the risk of the ruling. According to him, "It is practical for Cerrejón to be in a consultation process, because during the process it is not likely that communities will protest or make roadblocks" (personal communication March 2019). The strategy, he says, is "dividir y regalar" (divide and give gifts) (ibid.). For Cerrejón, he explained, the consultation process has been about discouraging levantamiento (uprisings) by giving just enough to quell protests.

\footnotetext{
${ }^{28}$ I.e. the modification, suspension or cancellation of the environmental license.

${ }^{29}$ The non-indigenous lawyer who represented Media Luna Dos was seen as a controversial figure because he closed the deal with Cerrejón questionably fast and soon thereafter collected signatures from more than one hundred communities, giving him power of attorney to represent them in the T-704/2016 legal process.

30 This informant also inferred that the salt byproduct from Cerrejón's desalination plant is being dumped back into the ocean, and that this may be driving away the fish.

${ }^{31}$ Observation at Seminar Transición Minero-Energético, Uni Magdalena, Santa Marta, April 2019.
} 
The international mining industry regards the consequences of the T-704/2016 ruling as "critical" and "disappointing"32 (observation at mining conferences, May 2018 and 2019). While a Cerrejón social standards manager also noted that the ruling presented an unprecedented challenge, she pointed out that it gave the corporation "an opportunity to improve dialogue in the long term" (personal communication February 2018). In this way, the ruling provides a platform to use consultation and incommensurable compensation as corporate social technologies.

If the company manages to get through the consultations with all communities in the zone of influence, the whole project - that has so often been criticized by national and international NGOs and activist groups is legalized anew. We argue that consultations and compensation schemes provide the opportunity for the legitimization of socioenvironmental damages while creating larger divisions in impacted communities, coopting leaders who were previously uncooperative, and slowly changing the image of the company from being violators (of rights) to victims (of activist courts). In that sense, the aftermath of the T-704/2016 ruling is being transformed into an unprecedented possibility for Cerrejón to "repair" its weak social license to operate, once and for all.

\section{Conclusion}

Our research demonstrates how compensation programs are incommensurable with the damage caused by the mining industry. Complimenting the literature on incommensurability, we found that the promise of compensation is a key component of corporate social technologies and works as a strategy of inclusionary control. The real purpose of such efforts is to discourage opposition from challenging institutional inequalities and damages from extractive practices. Even when hailed as a success by some, compensations act as a silencing mechanism masking the broader and more structural socioenvironmental damage done to local communities.

The three case studies provide complementary examples of how the consultation and compensation processes intend to make up for mining-related impacts and function in a paradoxical logic of equivalence by exacerbating already damaging extractive practices. The case of the Arroyo Bruno diversion shows how compensations cannot possibly address the environmental, socioeconomic and spiritual damage inflicted on local communities. The loss of the Bruno not only impacts Wayúu villages, it also threatens water security for the entire Guajira Peninsula. This case also highlights the inconsistencies in evaluating impacts, which can lead to some affected communities being left out of the consultation and compensation processes. When the company negotiates favorable compensation deals through selective local participation in negotiations, it burnishes its public image as a collaborative partner of the community. In addition to marketing the "responsible neighbor" trope, Cerrejón presents itself as a restorer of forests and a respecter of human rights. However, the practices assist to justify a project that is destructive to ecosystems, livelihoods and cultural practices. As such the case illustrates empirically how the corporate claim on commensurability is inherently a technology of power.

Our second case shows how Cerrejón's act of "giving" Provincial what the company touts as a generous compensation legitimizes damages in order to facilitate more extraction, ultimately benefiting the company while causing division in the Wayúu community. The social division serves the interest of the mining corporation by quelling resistance. Despite some tangible immediate improvements, such as a new internal road and a piece of land, the community still suffers from severe impacts of living next to an open pit coal mine. The case concretely illustrates that the community's internal division grows as the corporation insists that the damage can be compensated in monetary terms.

The last case explores the consequences of the tutela action made by the village Media Luna Dos as a response to not being consulted prior to the expansion of the coal port. Our research shows how this landmark ruling has so far failed to benefit the indigenous communities it claims to protect. If the company manages to get through consultations with all of the communities in the zone of influence, the whole project will then be legalized anew and politically legitimized. Despite the ruling being initially considered a big setback for the

\footnotetext{
32 The other mining companies' representatives referred to how Cerrejón had not been able to deliver as expected.
} 
company, Cerrejón, with the help of sympathetic state officials, turned the process into an opportunity to continue extracting while improving its public image.

By bringing into dialogue two sets of literature that have not earlier been combined in academic work, this article adds a Foucauldian power analysis of 'corporate social technologies' to the political ecology and environmental justice focus of incommensurability. Bringing together the two sets of literature contributes to a clearer understanding of how the corporate claim of commensurability between damage to human and nonhuman nature and monetary compensation is a tactic of power used as an attempt to mask the socioenvironmental damage. Explicitly pointing to the power dimension of incommensurability of compensation is arguably a point that is still often overlooked by researchers and practitioners in fields of human and environmental rights related to extractive industries. Long-term ethnographic fieldwork made this connection clear, provoking us to conduct the research and build around this central argument.

Our findings in the field and in our review of relevant historical, legal and academic sources lead us to conclude that the consultation and compensation processes for redress of mining damages - as well as the rules for the provision and renewals of environmental licenses to operate - are flawed. The process benefits extractive corporations and their allies in government. Further, considering the vastly hierarchical power imbalance between communities and the corporate and state representatives, consultation and compensation negotiations legitimize corporate practices, divide communities and suppress community resistance.

Direct actions, such as Provincial's early efforts to "stand strong against the company", which included an autonomous consultation process as an alternative to the officially established consulta previa procedures, and other instances of communities blocking the company's railway, are possible ways of making visible and/or resisting corporate divisive strategies. Other possible routes are calling for the rights of nature, as mentioned by Ulloa (2020). At the same time, challenging corporate social technologies provokes the risk of violence and threats to environmental defenders, creating further community divisions. As such, we do not suggest that resistance is an easy task. Exploring the divisive mechanisms of compensations offered by extractive corporations in other contexts, as well as how such strategies could be and are being challenged and resisted, could certainly be topics for more future research.

\section{References}

Adonteng-Kissi, O. 2017. Poverty and mine's compensation package: experiences of local farmers in Prestea mining community. Resources Policy 52: 226-234.

Allen, J. 2003. Lost geographies of power. Oxford: Wiley-Blackwell.

ANM. 2018. Por la cual se adoptan los términos de referencia aplicables para la elaboración de los programas y proyectos de Gestión Social en la ejecución de los proyectos mineros. Resolución 318 de 2018 | Agencia Nacional de Minería ANM.

Ballet, J., K. Lompo, and M.T. Randrianalijaona. 2019. Does the principle of compensation provide a solid basis for establishing corporate environmental responsibility: a case study of Madagascar's mining industry. EJBO Electronic Journal of Business Ethics and Organization Studies 24(1): 19-27.

Banks, E. 2017. We are Bruno: citizens caught between an absentee state and a state-like corporation during water conflicts in La Guajira, Colombia. Urban Anthropology and Studies of Cultural Systems and World Economic Development 46: 61-94.

Bebbington, A.J. 2010. Extractive industries and stunted states: conflict, responsibility and institutional change in the Andes. In K. Ravi Raman and R. D. Lipschutz (eds.). Corporate social responsibility: comparative critiques, international political economy series. Basingstoke: Palgrave Macmillan.

Bebbington, D.H. 2012. Consultation, compensation and conflict: natural gas extraction in Weenhayek territory, Bolivia. Journal of Latin American Geography 11(2): 49-71.

Bernays, E.L. 1947. The engineering of consent. The ANNALS of the American Academy of Political and Social Science 250(1): 113-120.

BNamericas. 2012. Cerrejón de Colombia suspende estudios por proyecto P500 para subir producción carbonífera. BNAmericas.com. 
Bowen, H.R. 1953. Social responsibilities of the businessman. New York: Harper.

Cabrera Leal, M., and J. Fierro Morales. 2013. Implicaciones ambientales y sociales del modelo extractivista en Colombia. In Garay Salamanca, L.J. (ed.) Minería en Colombia - Fundamentos para superar el modelo extractivista. Bogotá, Colombia: Contraloría General de la República.

CAJAR. 2019. Solicitud especial del cajar - acción de nulidad simple.

Calderón, J.T., R.M. Prada, and G.A. Loyo. 2013. Métodos de evaluación de impacto ambiental en Colombia. Revista de Investigación Agraria y Ambiental 4(2): 43-53.

Carmona, S., and P. Jaramillo. 2020. Anticipating futures through enactments of expertise: a case study of an environmental controversy in a coal mining region of Colombia. The Extractive Industries and Society S2214790X20301891.

Cerrejón. 2017. Informe de sostenibilidad 2017. http://www.cerrejon.com/wp-content/uploads/CERREJONINFORME_SOSTENIBILIDAD_2017-NOV14-2.pdf

Cerrejon.com. n.d. Proyecto La Puente. https://www.cerrejon.com/index.php/nuestra-operacion/proyecto-lapuente/ (last accessed 3 March 2020).

Coleman, L.M. 2018. Rights in a state of exception: the deadly colonial ethics of voluntary corporate responsibility for human rights. Oñati Socio-legal Series 8(6): 874-900.

Corte Constitucional. 2016. Sentencia T-704/16.

Costanza, J.N. 2016. Mining conflict and the politics of obtaining a social license: insight from Guatemala. World Development 79: 97-113.

Curvelo, W.G. 1991. The Guajira indigenous communities and the Cerrejón coal project. In Chomsky, A., G. Leech, and S. Striffler, (eds.). The people behind Colombian coal - mining, multinationals and human rights, pp. 46-52. Bogotá: Casa Editorial Pisando Callos.

DANE. 2019a. Pobreza monetaria por departamentos. https://www.dane.gov.co/index.php/estadisticas-portema/pobreza-y-condiciones-de-vida/pobreza-y-desigualdad/pobreza-monetaria-y-multidimensionalen-colombia-2018\#pobreza-por-departamentos-2018 (last accessed 28 May 2020).

DANE. 2019b. Pueblo Wayúu. Resultados del censo nacional de población y vivienda 2018. Gobierno de Colombia. $\quad$ https://www.dane.gov.co/files/censo2018/informacion-tecnica/presentacionesterritorio/190816-CNPV-presentacion-Resultados-Guajira-Pueblo-Wayuu.pdf(last accessed 20 May 2020).

Dunlap, A. 2018. "A bureaucratic trap:" free, prior and informed consent (FPIC) and wind energy development in Juchitán, Mexico. Capitalism Nature Socialism 29(4): 88-108.

Dunlap, A. 2020. Wind, coal, and copper: the politics of land grabbing, counterinsurgency, and the social engineering of extraction. Globalizations 17(4): 661-682.

Dunlap, A., and J. Fairhead. 2014. The militarization and marketization of nature: an alternative lens to 'climateconflict.' Geopolitics 19(4): 937-961.

Fajardo Gómez, R. 2007. The systematic violations of the human rights of the Indigenous people, Black people and campesinos by the coal mining multinationals in the department of La Guajira, Colombia. In Chomsky, A., G. Leech, and S. Striffler, (eds.) The people behind Colombian coal - mining, multinationals and human rights, pp. 16-28. Bogotá: Casa Editorial Pisando Callos.

Fetterman, D.M. 2010. Ethnography: step-by-step. 3rd ed. Los Angeles: Sage.

Flemmer, R., and A. Schilling-Vacaflor. 2016. Unfulfilled promises of the consultation approach: the limits to effective indigenous participation in Bolivia's and Peru's extractive industries. Third World Quarterly 37(1): 172-188.

Fontana, L.B., and J. Grugel. 2016. The politics of Indigenous participation through "free prior informed consent": reflections from the Bolivian case. World Development 77: 249-261.

Foucault, M. 1991[1977]. Discipline and punish: the birth of the prison. London: Penguin Books.

Franco, J. 2014. Reclaiming Free Prior and Informed Consent (FPIC) in the context of global land grabs. Transnational Institute and Hands off the Land Alliance. 
Frederiksen, T., and M. Himley. 2020. Tactics of dispossession: access, power, and subjectivity at the extractive frontier. Transactions of the Institute of British Geographers 45: 50-64.

Gilbertson, T.L., 2020. Financialization of nature and climate change policy: implications for mining-impacted Afro-Colombian communities. Community Development Journal 56(1): 21-38.

Guerra Curvelo, W. 2002. La disputa y la palabra: la ley en la sociedad wayuu. Bogotá: Ministerio de cultura.

Hernandez, D.P. 1983. Socio-cultural and environmental studies - impact of the Cerrejón mine and the Wayúu. In Chomsky, A., G. Leech, and S. Striffler, (eds.) The people behind Colombian coal - mining, multinationals and human rights, pp. 37-45. Bogotá: Casa Editorial Pisando Callos.

Hilson, G. 2002. An overview of land use conflicts in mining communities. Land Use Policy 19(1): 65-73.

ILO. 1989. Indigenous and tribal peoples convention. https://www.ilo.org/dyn/normlex/en/f?p=NORMLEXPUB:12100:0::NO::P12100_ILO_CODE:C169 (last accessed 25 May 2020).

Jakobsen, L.J. 2020. Corporate security technologies: managing life and death along a Colombian coal railway. Political Geography 83: 102273.

Kidido, J.K., J.Z. Ayitey, E.D. Kuusaana, and E.K. Gavu. 2015. Who is the rightful recipient of mining compensation for land use deprivation in Ghana? Resources Policy 43: 19-27.

Kirsch, S. 2014. Mining capitalism: the relationship between corporations and their critics. Oakland: University of California Press.

Le Billon, P., M.C. Roa-García, and A.R. López-Granada. 2020. Territorial peace and gold mining in Colombia: local peacebuilding, bottom-up development and the defense of territories. Conflict, Security \& Development 20: 1-31.

Li, F. 2011. Engineering responsibility. Focaal 60: 61-73.

Machado, M., D. López Matta, M.M. Campo, A. Escobar, and V. Weitzner. 2017. Weaving hope in ancestral Black territories in Colombia: the reach and limitations of free, prior, and informed consultation and consent. Third World Quarterly 38(5): 1075-1091.

Macías Gómez, L.F. 2020. Colombia: environment and climate change law 2020. iclg.com. https://iclg.com/practice-areas/environment-and-climate-change-laws-and-regulations/colombia (last accessed 12 February 2020).

Martinez-Alier, J. 2001. Mining conflicts, environmental justice, and valuation. Journal of Hazardous Materials 86(1-3): 153-170.

McLeod, H. 2000. Compensation for landowners affected by mineral development: the Fikian experience. Resources Policy 26(2): 114-125.

McNeish, J.A. 2017. Extracting justice? Colombia's commitment to mining and energy as a foundation for peace. The International Journal of Human Rights 21(4): 500-516.

Ministerio de Ambiente y Desarrollo Sostenible. 2012. Manual para la asignación de compensaciones por pérdida de biodiversidad. https://www.minambiente.gov.co/images/BosquesBiodiversidadyServiciosEcosistemicos/pdf/gestion en_biodiversidad/180912_manual_compensaciones.pdf (last accessed 5 March 2020).

Ministerio de Ambiente y Desarrollo Sostenible. 2015. Decreto 2041. Por el cual se reglamenta el Título VIII de la Ley 99 de 1993 sobre licencias ambientales.

Owen, J.R., and D. Kemp. 2017. Extractive relations: countervailing power and the global mining industry. London: Routledge.

Pardo, L.A.B. 2018. Extractivismo, derechos y tributación: cooptación del Estado colombiano. Un caso de estudio. Ideas verdes 11: 1-36. Fundación Heinrich Böll Oficina Bogotá - Colombia. https://co.boell.org/sites/default/files/20181003_ideas_verdes_11_web.pdf (last accessed 18 Dec. 2020).

Pellegrini, L., and M.O.R. Arismendi. 2012. Consultation, compensation and extraction in Bolivia after the "left turn": the case of oil exploration in the north of La Paz department. Journal of Latin American 
Geography 11(2): 103-120.

Perrin, M. 1995. Los practicantes del sueño. El chamanismo Wayúu. Caracas: Monte Avila Latinoamérica.

Polo Figueroa, N. 2017. La palabra en la cultura wayúu. Cuadernos de Lingüística Hispánica 30. http://revistas.uptc.edu.co/revistas/index.php/linguistica_hispanica/article/view/6187 (last accessed 4 August 2020).

Posada, A. R. 2020. El exterminio por sed de los wayuus. ONIC.org.co. https://www.onic.org.co/comunicadosregionales/3612-el-exterminio-por-sed-de-los-wayuus (last accessed 11 February 2020).

Prno, J., and S.D. Slocombe. 2012. Exploring the origins of 'social license to operate' in the mining sector: perspectives from governance and sustainability theories. Resources Policy 37(3): 346-357.

Rogers, D. 2012. The materiality of the corporation: oil, gas, and corporate social technologies in the remaking of a Russian region. American Ethnologist 39(2): 284-296.

Rojas-Páez, G. 2017. Understanding environmental harm and justice claims in the Global South: crimes of the powerful and peoples' resistance. In Rodríguez Goyes, D., H. Mol, A. Brisman, and N. South, (eds.). Environmental Crime in Latin America, pp. 57-83. London: Palgrave Macmillan.

Ruggie, J.G. 2007. Business and human rights: the evolving international agenda. SSRN Electronic Journal. http://www.ssrn.com/abstract=976547 (last accessed 30 March 2020).

Schilling-Vacaflor, A., and J. Eichler. 2017. The shady side of consultation and compensation: 'divide -andrule tactics in Bolivia's extraction sector. Development and Change 48(6): 1439-1463.

Spash, C.L., and I. Aslaksen. 2015. Re-establishing an ecological discourse in the policy debate over how to value ecosystems and biodiversity. Journal of Environmental Management 159: 245-253.

Strambo, C., A.C. González Espinosa, A.J. Puertas Velasco, and L.M. Mateus Molano. 2020. Contention strikes back? The discursive, instrumental and institutional tactics implemented by coal sector incumbents in Colombia. Energy Research \& Social Science 59: 101280.

Trainor, S.F. 2006. Realms of value: conflicting natural resource values and incommensurability. Environmental Values 15(1): 3-29.

Ulloa, A. 2020. The rights of the Wayúu people and water in the context of mining in La Guajira, Colombia: demands of relational water justice. Human Geography 13(1): 6-15.

Utting, P. 2008. The struggle for corporate accountability. Development and Change 39(6): 959-975.

Wall, E., and R. Pelon. 2011. Sharing mining benefits in developing countries. Washington, DC: World Bank. http://documents.worldbank.org/curated/en/359961468337254127/Sharing-mining-benefits-indeveloping-countries (last accessed 3 March 2020).

Warnaars, X.S. 2012. Why be poor when we can be rich? Constructing responsible mining in El Pangui, Ecuador. Resources Policy 37(2): 223-232.

Watson, L. 1981. Dreaming as world view and action in Guajiro culture. Journal of Latin American Lore 7(2): 239-254. 